\title{
Conjuring Trauma with (Self)Derision: The African and African-American Epistolary Fiction
}

\author{
Ousmane Ngom ${ }^{1}$ \\ Université Gaston Berger, St-Louis \\ Départementd'Anglais, Senegal
}

Doi: 10.19044/esj.2018.v14n2p1 URL:http://dx.doi.org/10.19044/esj.2018.v14n2p1

\begin{abstract}
All the female narrators of the three stories examined here - So Long a Letter, The Color Purple, and Letters from France - suffer serious traumas attributable to their male counterparts. Thus as a healing process, letter-writing is an exercise in trust that traverses the distances between the addresser and the addressee. Blurring the lines in such a way results in an intimate narration of trauma that reads as a stream of consciousness, devoid of fear of judgment or retribution. This paper studies the literary device of derision coupled with a psycho-feminist analysis to retrace the thorny, cathartic journey of trauma victims from self-hate to self-acceptance and self-agency.
\end{abstract}

Keywords: Feminism, trauma, derision, self-derision, genderlect, self-hate, catharsis, self-agency, epistolary

\section{Introduction}

Fiction writers and activists Mariama $\mathrm{Ba}$, Sembène Ousmane and Alice Walker have gained wide critical acclaim. Their literary works are described by critics as feminist, meaning work that exposes women's conditions from women's viewpoints. Ba is considered as a pioneer of African feminism. Walker is an American feminist who introduced the notion of "womanism" to the feminist movement, stating that "womanism is to feminism as purple is to lavender" (Walker, 1983: author's notes). She further expands the definition of love to include physical relationships, giving women increased language and ownership over their sexualities (Walker, 1983: author's notes). Though a man, Sembène is distinguished by the particularly

\footnotetext{
${ }^{1}$ I express my heartfelt gratitude to Emily Gaynor for her insightful comments, suggestions, and edits on an earlier version of this paper. I extend my appreciation to Jeffrey Lue; both made my research stay in Wisconsin pleasant and fruitful.

I also thank James Delehanty and the African Studies Department for the tremendous resources they made available to me, the Bellinger and O'Connor families for their hospitality.
} 
privileged place women and women's concern occupy in his work (Madubuike, 1979; Azodo, 1997: 202; Kamara, 2001: 223).

Scrutinizing their epistolary fictions shows the authors' commitment to women's liberation from patriarchal institutions. Ba's So Long a Letter portrays Ramatoulaye, herself a byproduct of the French education system, confronted by the heavily patriarchal Senegalese society and the institution of polygamy. With Nafi, Sembène's character in Letters from France, the plight of immigrant African women is highlighted. The Color Purple dramatizes the turmoil of Celie, an African-American girl, in a society still processing the stigmas of slavery. The textual structure and ideological claims of these works are based on the feminist premise that men are responsible for women's problems. In fact, each of the main characters suffers from traumatic ordeals that trigger the need to write letters as an excretory experience. The framework of the present article uses the conventional definition of "trauma" shared by Atkinson as "any safety-threatening event that 1) is sudden, unexpected, or not normal in a person's experiences; 2) exceeds the individual's perceived ability to cope; and 3) disrupts the individual's mental and emotional functioning in a way that interferes with activities of daily living" (Atkinson, 2008: 21).

The aim of this paper is to focus on the particularly derisive language of the letters used by each main character to address trauma. Derision can blend humor and satire, and according to Bonnafous, derision is verbal violence that associates humor and aggression (Bonnafous, 2001: 53). I postulate that the structural evolution of the narrative, paralleling the character development, is mirrored by the shifts in the use of derision. The first part of this paper shows how the self-derision of trauma victims translates as selfhatred. The second section deals with the subversive self/derision for the transgressions of the hegemonic patriarchal structures. The last part deals with self/derision as a catharsis tool through transcendence and self-acceptance.

\section{Self-derision: a mirror of post-traumatic self-hate}

The epistlers of the three stories -Ramatoulaye, Nafi, and Celie - write to their dearest female friends, an expression of sisterhood. In this case, writing is an exercise in trust that traverses the distances between the narrator and the implied narratee. Blurring thus the lines between a main character and her receptor results in an intimate narration that reads as a stream of consciousness, devoid of fear of judgment or retribution. In fact, throughout the three stories, the narrators point to long-standing friendships and even family kinships to empower the letter recipient and justify why they lean on her in these moments of torment. According to Coulibaly, the reader or audience plays an important role in the process of victims' trauma healing (2017: 112-113). 
These victims of injustice, resulting mainly from patriarchal societies, are terribly lonely characters, suffering from layers of abandonment and confinement and are often found chasing further abasement. On one hand, they are often found guilty of self-humiliation, displaying self-hate that stems from the demeaning psychosis of the oppressed who eventually believe they deserve what befalls them. Reflecting on their lives brings disappointment, "despair and depression". At this point, the letter-writing process can be considered as "self-torturing ruminations" of characters "psychologically beating (themselves) unmercifully" (Rubin, 1998: 15). They are in fact seeing themselves through the deforming and depersonalizing prism lens of the discriminatory society.

On the other hand, despite their dreadful plight, these narrators sometimes find the courage and strength to derisively mock themselves and their society. Self-derision is then used as a way out of their otherwise gloomy predicaments. Mocking at oneself and at society can appease the heart and alleviate the soul's burden.

As she shares in her missives, Ramatoulaye is abandoned by her husband, who leaves her to suffer with the burden of providing for their family, while he chases a younger woman, their own daughter's classmate. Throughout the novel, "the husband is an active, totally willing participant and instigator of the dilemma" (Kamara, 2001: 218). But Ramatoulaye's drama resides more in her internal conflicts than the external one, between her rebelling self that yearns for emotional freedom and the policed self who she knows must cope with established norms: "My heart concurs with the demands of religion. Reared since childhood in their strict precepts, I expect not to fail" (8). This education of submission is inculcated by her parents, society, and religion. It bangs together with her education which normalized self-assertiveness and progressiveness, as "the first pioneers of the promotion of African women" (15).

The way she narrates these conflicting situations is through sarcasm. She describes herself as a torn individual aspiring for evolution, but not badly enough to break away from the restraints of traditional norms. Whatever the situation, she desires to give good impression, to act according to the mores of society and religion.

She even willingly bears what she admits as the heavy burden of the oppressive and exploitative system of marriage in which the wife should kneel down before her in-laws and satisfy their whims to secure their 'love'. She clearly identifies the marital institution as a great swindle, all the more so since the wife lives in constant threat of being misjudged. As such, "she sacrifices her possessions as gifts to her family-in-law; and worse still, beyond her possessions she gives up her personality, her dignity, becoming a thing at the service of the man who has married her [...]" (4). In fact, the narrator shows 
the extent to which the wife should strip herself from self-pride to sacrifice herself for the satisfaction of her in-laws.

The narration of the stealthy dating and later marriage of her husband with Binetou is ironic since the narrator initially doesn't grasp the significance of all that revolves around her. When she does, it is too late. She relates her naivety, being conned into a puppet by her husband and, even worse, by Binetou, her daughter's classmate. Paradoxically, she unknowingly contributed to the conditions around her downfall by welcoming Binetou into her house with open arms.

Ramatoulaye's dramatic revelation of Binetou's marriage is worth noting. Seeing the three emissaries of her husband without him, she wonders where her husband could be. At the height of the climax, seized by panic, she hoarsely inquires if there is anything that matters with Modou. The Imam then takes up the opportunity to pull down the tension with sadistic sarcasm: "Yes, Modou Fall, but, happily, he is alive for you, for all of us, thanks be to God. All he has done is to marry a second wife today" (37). The way they minimize or downplay this life-changing information demonstrates the nature of the patriarchal society and the norm of polygamy which by no means takes a woman's opinion into consideration. (Linkhorn, 1986: 71). Ramatoulaye uses dark humor to relate the event and her reaction to it - a modern woman tormenting, even torturing herself in order to be appreciated in society:

I forced myself to check my inner agitation. Above all, I must not give my visitors the pleasure of relating my distress. Smile, take the matter lightly, just as they announced it. Thank them for the humane way in which they have accomplished their mission. Send thanks to Modou, 'a good father and a good husband', 'a husband becomes a friend'. Thank my familyin-law, the Imam, Mawdo. Smile. Give them something to drink. See them out, under the swirls of incense that they were sniffing once again. Shake their hands. (38)

This passage is self-derisive, as the character attempts to straddle two conflicting roles. She entirely disapproves of her husband's devious marriage as well as the indifferent and carefree way his messengers impart this bad piece of news. Nevertheless, she is compelled by tradition to cope and, much worse, to show happiness and joy in this bleak situation. Therefore, we recognize Ramatoulaye's two contradictory voices in the Bakhtinian acceptance of the term dialogism. While she "laughs with them", smiles, thanks them "for the humane way" in which they have announced the piece of news, and lauds her 
husband and family-in-law, she suppresses her genuine feelings and beliefs. Her words demonstrate her desire to maintain her good societal standing. .

Ramatoulaye's is not an ironic speech, for it is not a "word of spirit" in the Freudian sense. In fact, if irony is a figure of speech that consists of saying the contrary of what should be understood, it necessarily must mean that the intention of the speech is to be perceived as such (Fontanier: 1977). In fact, a "device" [is] an all-purpose term used to describe any literary technique deliberately employed to achieve a specific effect" (Baldick: 64). Based on the principle of intentionality and purpose, one can observe that Ramatoulaye's words fail to comply with these principles and therefore to enable the detection of the gap between the speech and the real thoughts of the character (Rainville: 122). Consequently Ramatoulaye's discourse is self-derisive, as she controls herself in order to save face. She clearly identifies her oppressors, but doesn't resist their wills, doesn't even want them to know she is unhappy with the ways she is treated. So she bitterly plays a tragic, self-destructive role, as she admits: "I acquiesced under the drops of poison that were burning me" (37).

"Based on the idea of global sisterhood whereby all women have the same plights and aspirations" (Guèye, Marame 2012: 6), the three stories sustain the feminist stance which holds that men are, more often than not, directly responsible for women's traumas (Hamilton, 381). In fact, like Ramatoulaye, the narrators of the two other stories face traumas which stem directly from men's actions, and like Ramatoulaye, these characters react to their situations by indulging in self-criticism and self-torturing. For instance, Ramatoulaye points to her weak character compared to her friend Aissatou who was immigrated in the U.S. after divorcing her husband when he takes a second wife. Both Ramatoulaye and Aissatou have been influenced by French cultural norms; they hold the westernized, romantic conception of marriage as "the total surrender of oneself to the person one has chosen and who has chosen you" (56).

However, they differ in the way they manifest the pursuit of their aspirations. Ramatoulaye's resignation makes her life a vortex of traumas, as her acceptance of a co-wife results only in abandonment. "From then on, my life has changed. I had prepared myself for equal sharing according to the precepts of Islam concerning polygamic life. I was left with empty hands" (46). Her horizon is blocked because she can't conceive her life outside the realm of marriage: "Waiting! But waiting for what? I was not divorced...I was abandoned: a fluttering leaf that no hand dares to pick up (...)" (53). Describing herself as a "fluttering leaf" is self-depreciative, but it echoes the society's conception of marriage as a standard to measure women's value.

This acceptance of her weakness of character and inability to fathom modernity provide a disparaging self-portraiture that Ramatoulaye shares with Nafi and Celie. Indeed, all the three characters are initially conditioned by their 
social environments and, seeing themselves through the derogatory eyes of society, they eventually despise themselves.

Nafi is doubly isolated in a foreign country, victim of both racism and sexism. However, she blames herself for her plight. She is disappointed in the mirage of France and in her marriage to a septuagenarian. This misfortune can be traced to the moment her father shows her a photograph of a man who wanted to marry her. The photo presents the man as a young adult. She consents to marry him because she has always dreamed of France. Once in France, she discovers that the man lied about his age, the quality of his health, and his societal standing. She knows nothing more of France than the damp, sunless room where she lives as a recluse. This confinement negatively impacts her nervous condition.

More tragically, Nafi hates herself more than her father and her husband, the two men actually responsible for her ordeal (Linkhorn, 1986: 71). She even thinks that she is the only person to be held responsible for her condition: "I find consolation in the fact that I brought misfortunes on myself" (59). However, this attitude is merely a justification to avoid facing her reality. All through her epistles, she returns to the landmark photograph her father showed her. Describing the life she's leading in France, she says this: "It's a martyrdom - and all because of a photograph" (75). Her obsessive references to the photograph translate to her psychological trauma, referred to by psychologists as the impossibility or difficulty to cease experiencing the haunting images and nightmares. "A photo taken twenty years ago! And like a perfect idiot, I was taken in by it. By a photo that had been touched up!" (57).

Negatively characterizing herself as "a perfect idiot", "poor stupid fool" is informative of this character's practice of self-flogging. Her state of mind is all the more problematic as she knows, all too well, that she is victim of a male conspiracy in which her father took an active part. Nevertheless, she continuously denies the idea of her father's participation; and worse, instead of feeling hatred for her husband who is undeniably guilty, she despises herself. Telling examples in this paradoxical relationship manifest where motifs for hating her husband transform into motifs for hating herself. This fact is apparent in her missives through the example of her reaction to the traumatic sexual act with her husband.

In fact, Nafi finds her husband old, unhygienic, and absolutely repulsive, but this sentiment is paradoxically excessively self-destructive: "There are times when I wish I could catch some awful disease, an illness with running sores, so that my appearance would put him off and he would not want to touch me" (58). "I suffer from not being ill" (58). Or still "I detest him to the point of hating my own body" (59). Her case is reminiscent of the treatment in African and African-American literature of blacks who, finding no 
alternative, would kill themselves or their dear relatives, or would cause themselves severe physical harm to save themselves from the claws of slavetraders (Ngom 2012: 58). In truth, Nafi considers her husband's visits as rape. As with many rape victims, Nafi hates her own body which she considers stained. Worse, she lives with her rapist who has legal rights to share her bed. She is no longer interested in taking care of her body; she wastes away, even wishing to die to get away from her husband.

Similarly to Nafi, Celie, in The Color Purple, is repeatedly raped by her stepfather, who makes her pregnant twice and drives the resultant children and later Celie herself away in order to eradicate the proof of his incest. In fact, as Worthington observes, "Celie is a reminder to him of his sexual abuse. To get rid of her and his guilt, he marries Celie to Mr. -" (Worthington, 1985: 49).

The Color Purple opens by this frightening epigraph engraved on the pediment of Celie's subconscious: "You better not never tell nobody but God. It'd kill your mammy" (1). This threatening paternal injunction of silence (Abbandonato, 1991: 1106; Tucker, 1988: 83) alludes to unspeakable pains and reveals the seriousness of the narrative. Cut off from the world, surrounded by a father who has disappointed her, unable to open herself to her ailing mother, or to her younger sister, she resolves to engage in a secret conversation with God.

The first letter shows a fragile and lost teenager, prey to existential doubts: "Dear God, I am fourteen years old. I am I have always been a good girl. Maybe you can give me a sign letting me know what is happening to me" (1). Read through the lens of textual genetic theory, which gives credence to the study of erasures in text production (Rey-Debove, 1982; Doquet \& Leblay, 2014), one infers that Celie's hesitation and the tense shifts in her writing are informative of her psychological doubts. The lost child who asks for divine guidance doubts whether or not she is guilty of a crime committed by her stepfather. These attitudes of reflexive moral violence derive from the fact that victims of rape often feel guilty or are considered guilty by their relatives for at least the crime of provocation.

Consequently, these traumatic events trigger self-hate and selfrejection in Celie who eventually, like many victims of rape, considers her body as a strange, awful thing that doesn't belong to her. "Indeed, what could be more destructive to a woman's body than rape?" (Doquetet Leblay, 2014:40). This is why when Celie later marries, she resents her husband. Sexual intercourse with him is torture from which no pleasure is derived. For this reason, at least until her encounter with Shug, she considers herself a virgin. The novel hints at lesbianism, as the main character abhors sex with men and always associates it with dirt and brutality. Celie views sex with her husband as nasty, particularly because she does not feel anything while her 
husband concerns himself with doing his business and leaving. This is further humiliation to her as she thinks her body is the receptacle of a man's dirt, and in fact, relating the sexual parties with Albert, "[She] make(s) it sound like he going to the toilet on [her]" (77).

Furthermore in her letters, Celie casts a negative self-portraiture, describing herself as dumb and ugly. She fits into the large category of rape victims who feel they are "scarred for life, worthless, damaged, filthy, unknowable" (Atkinson, 2008: 14). Her case is further aggravated by her stepfather who withdraws her from school and pretends she is dumb, completely disregarding her school-teacher and Netty's beliefs that Celie is intelligent and has good academic potential. After repeatedly hearing that she is an idiot, Celie eventually accepts and repeats this derisive characterization. That perpetuates a vicious cycle, as she ultimately endorses society's judgment of her, believing she's ugly, stupid, and ne'er-do-well. Accepting society's canon of beauty and intelligence embodied through personal refinement and school education, she envies Shug and her sister Netty for they signify black society's perfection. Speaking about Shug, Celie says: "She [Shug] bout ten thousand times more prettier then me" (6). She also wishes she had her sister's formal way of speaking and her good spirit.

Celie is like a fruitless tree, one that is prevented from germinating. Her hard experience endangers her personal development. Being terrorized and traumatized in her infancy by a rapist father causes deterioration of her character. She is not self-assertive. Rather she is timid, fearful, and does not fight back. In fact, she cannot even stand up to children, much less adult men: "But I don't know how to fight. All I know how to do is to stay alive" (17). "I shrug my shoulders. This life soon be over, I say. Heaven last all ways" (42). Indeed, she believes that men's physical abuse of their wives is normal. This translates to her acceptance of the existing social order, shown when she advises her stepson Harpo to beat his wife to make her submit to him.

Paraphrasing McDowell, one can say that Walker, Ba and Sembène reveal their heroines' characters completely from the inside. Everything we learn about them filters through their own consciousness and renders in their own voice (McDowell, 289). Through their letters, one can trace the mental and psychological evolution of these characters from self-hate - shown through self-derision - to the reclaiming of selfhood that starts with debunking social taboos.

\section{Transgressing patriarchal structures with derision}

Through the progression of the novels, the characters reveal a development of habits of breaking secular taboos found within entrenched institutions like marriage, religion, and social values. As Rainville puts it, transgression that is peculiar to derision, always goes with contestation 
(Rainville, 2015: 51). So the stories of the corpus question the status-quo by attacking dominant patriarchal institutions. Hence, we observe through characters' dimensions of derision their aims to disqualify the patriarchy through ridiculousness (Bonnafous, 2001: 55).

The portraiture of the male characters through the lens of the feminist letter writers reveals a derisive description of "men as being morally bankrupt, cold-hearted, deplorably ungrateful, and sexually exploitative" (Kamara, 2001: 221). Indeed, men are considered villainous, hindering women's social emancipation through the hallmark of their masculinity. "They are all characterized by a certain sense of irresponsibility and by the manifestation of a far too dominant sense of individualism" (Guèye, Médoune, 2003).

According to linguists, different environments and social structures nurture different concerns and therefore produce sociolect, or the dialects of particular social classes (Lewandowski, 2010: 61). Likewise, different genders are required to use their specific linguistic dialects to convey their different or divergent purposes. This specificity in discourse production, based on gender determination, is called genderlect, a term coined by Deborah Tannen. The woman-narrator of each story views men from her own feminist perspective. The male characters are, more often than not, characterized as brutal buffoons imposing authority, or immature grownups with reckless sexual impulse. Their arrogant, contemptuous attitudes and discourses are analyzed by the narrators who have a view to exposing the men's irrationalities which are only motivated by perpetuating their hegemony.

All three narrators consider men as strange beings, perhaps even creatures from another planet. Raped by her stepfather, Celie is scared of men, and she indiscriminately avoids them: "Most times mens look pretty much alike to me" (15); "Men look like frogs" (254). And Ramatoulaye reinforces: "[...] Mawdo, and through him all men, remained an enigma to me" (33). In fact, since she has been betrayed by her husband in whom she placed an unwavering trust, Ramatoulaye considers that men are puzzling beings she can never understand because of their slyness and versatility. That is why a good part of her narrative is devoted to looking for explanations as to what has caused this hitherto responsible family man, respected by his peers and colleagues, to lose his head for his daughter's classmate, going even to the extent of abandoning his family.

The narrative of the incident displays a derisive description of a false man; a "walking lie", as Fanon would put it, trying so desperately and absurdly to look young. "And Modou would dye his hair every month. His waistline painfully restrained by old-fashioned trousers, Binetou would never miss a chance of laughing wickedly at him. Modou would leave himself winded trying to imprison youth in its decline, which abandoned him on all sides" (48). In fact, 'In describing Modou's 'legalized' affair with young Binetou, 
the narrator borrows a quite derisive and ironic tone drawing attention on the ridiculous and pathetic sides of his behavior" (Dieng, 2011:30).

Playing young is laughable for this man, as he is an outcast who neither fits in his old-fashioned suits, nor is comfortable in the clubs he frequents to conquer Binetou's heart. Modou's resoluteness to marry Binetou despite the latter's mockery is telling. He is fully aware of Binetou's interest in the relationship; she considers him a sugar daddy to be ridiculed at every turn. However, he exploits her and her family's vulnerability, conquering their hearts through ostentatious presents. For instance, he "offers her a villa, Mecca for her parents, a car, a monthly allowance, jewels" (35). The tragic irony of the situation resides in the fact that at the same time he is starving his first family, he is crippled by debts to please the desires of his second in-laws.

Though very indecent, Mawdo's justification after finding a co-wife for his devoted spouse Aissatou helps Ramatoulaye better fathom her own husband's motive for marrying Binetou. She insists that Mawdo's justification for his act is groundless, as he pretends to have acted, not out of love, but on his mother's injunction. When the narrator mockingly confronts him about his wife's repeated pregnancies, signs of their frequent intimacies, Mawdo's answer leaves her puzzled. He invokes the "imperious laws" that guide the male's instinct. As he contends, women are as indispensable to a man as food and clothing. Therefore, for the sake of variety, men have the right to change their partners: "A wife must understand, once and for all, and must forgive; she must not worry herself about "betrayals of the flesh" (34). For Ramatoulaye, men's conception of love, separating the heart and the flesh, is intriguing. Commenting on this speech, she finds Mawdo's comparison which reduced women to a "plate of food" inordinately disrespectful (34).

In the same vein, the epithets both Nafi and Celie use for their husbands are "the swine" or "the pig", pointing at their bestiality and insatiable lust. The two narrators' repugnance to call their husbands by their names is illustrative of hatred and could indicate that the names are infected to the point of staining whoever touches them. The insistence of Nafi on the word my "husband", set off between quotation marks, can be interpreted as ironic. She does so in order to distance herself from the word husband since hers entirely lacks all the sense, value, and quality usually attached to the bearer of this title.

Indeed, Nafi finds everything related to her husband ironic, because he proves to be the opposite of what one usually expects from the institution of marriage. Contrary to what he made her believe, he is old, illiterate, jobless, mischievous, unhygienic, and lustful. Not only has he fooled her into marrying him by relying on an edited photo taken twenty years earlier, he also imposes on her the humiliation of begging for employment on his behalf, when in fact he reached retirement age five years ago. In addition, she has to face the incriminating gaze of society which finds the age difference in the couple 
outrageous. In their judging looks, she hears their comments about "your daddy of a husband" (54).

Furthermore, everything which is supposed to bring joy in normal marital life turns out to be distressful for Nafi, thus the use of oxymoron which abounds in her descriptions of her husband and her life in France. In her school days, Nafi dreamed of a modern marriage, had high expectations, and set high standards for her future husband. Above all, she, as most people of her generation, was fascinated by the mirage of the Mother country, echoing the famous expression then in vogue: "to see Paris and die." Nevertheless, her dreams of France turned into the worst nightmare. For instance, writing to her friend after six months in France, she hastens to specify: "Don't tell me time passes quickly. Half a year in hell would have been sweeter" (57). In the same token, she gives way to her frustration by portraying her husband in the most derogatory ways, using oxymoron and antithesis expressions:

"His job is being out of work. That's lasted five years" (57); "He is more often in the room, with his foul smell, than out in the street. His mere presence fills me with disgust, more and more so. All his kindness and fond attention irritate me" (60). Considering she was fooled into a trap, she still can't afford a divorce, as she is far from home and penniless. This leaves her helpless: "The swine, they've really got me" (75).

In addition to the moral and psychological violence noticed in So Long a Letter a Letter and Letters from France, The Color Purple bears the humiliating marks of physical and sexual violence. In this novel, men want to mutilate and silence their female counterparts through beatings and rape. The narrator demonstrates the male discourse that serves as rationale to this practice. For instance, Albert beats Celie for any trivial pretexts and the answer he gives to his questioning son is clear-cut: "Wives is like children. You have to let 'em know who got the upper hand. Nothing can do that better than a good sound beating" (35). Through this reply, Walker reveals the socialization at work in this patriarchal society. She "takes us back into the black psyche, a return visit to the cultural poverty, where families pass on the pathologies of life to successive generations" (Hamilton, 1988: 380).

In fact, though just a boy, Harpo is already a chauvinist who doesn't move the slightest finger as long as Celie is around. Later, when he gets married, he tries, with no success though, to reproduce the violence-baseddomination pattern he observed during his childhood. What intrigues Celie is why Harpo can't pay attention to and content himself with the physical beauty and moral qualities of his wife, instead of seeking to turn her into a submissive wife: "Sofia love you, she a good wife. Good to the children and good looking. Hardworking, Godfearing and clean" (62). However, Harpo finds Sofia "strong headed," and he wants her to be as docile as Celie, to always silently accept everything no matter what. This is the ideal wife for chauvinistic men 
like Harpo. In Ramatoulaye's situation, she is praised for being docile, and Nafi is always encouraged by her father to obey her husband and to behave conformingly to the society's norms.

Male hegemonic discourse towards woman is full of arrogance. The words that the authors put in the mouths of their male characters are disrespectful. At best, they consider women as children, sexual objects, much less than human. Putting such discriminatory discourses in the mouths of the male characters is parodic, a discursive strategy to shed light on their idiocy.

The passage where Celie's stepfather tries to get rid of her by marrying her away is all the more humiliating as it recalls the infamous slavery bargaining. On top of his horse, Albert takes a good look of Celie, who is encouraged by her stepfather, as if he is a slave trader, evaluating his goods. He makes her turn around for Albert to appreciate all of her body. Her stepfather warns Albert that she is ugly and not a virgin, but these shortcomings are countered by her moral qualities: she is docile, clean, hardworking, and she loves children (8).

When the stepfather reveals "She ain't fresh [...]. She spoiled. Twice" (8). What he doesn't say is that he is the cause of those pregnancies. In this society, a raped woman can't denounce her rapists lest they should be held responsible for being raped. They face sordid situations forthe reversal of the guilt. The most outstanding example is Harpo's mother, who is blamed for being killed. That is the reason why the father of the girl that Harpo dates doesn't want him to marry her. In addition, Harpo's father humiliates Harpo's girlfriend asking who's responsible for her pregnancy. Despite the girl's shock, he presses on: "Young womens no good these days [...]. Got they legs open to every Tom, Dick and Harry" (31). The tragic irony of the hypocrite society stands on the fact that Albert doesn't grow wise; he is mechanically repeating the pattern he suffered from in the past when his own father stood against him to marry Shug because she had children out of wedlock, whereas the fact that these were Albert's left him stone still. This is a caricatured exposure of the falsity, the irrationality of the male discourse that demands a "fresh," virgin wife while considering girls as objects to conquer.

In So Long a Letter, Tamsir's declaration of love to Ramatoulaye - his younger brother's widow - demonstrates man's assurance of the matter-offact nature of his will. By the end of Ramatoulaye's widowhood, he informs her: "when you have 'come out' (that is to say of mourning), I shall marry you. You suit me as a wife [...]. Usually it is the younger brother who inherits his elder brother's wife. In this case, it is the opposite. You are my good luck. I shall marry you" (57). Tamsir's arrogance can be explained by the fact that he takes for granted that women don't have any choice because they are not their own masters. Ramatoulaye, like many women who marry in a patriarchal society, leaves her father's ownership to get into her husband's. For that 
reason, she is now her dead husband's family's property, and they can dispose of her as they will. For Tamsir, that Ramatoulaye becomes his wife is only a formality.

Religion, or a patriarchal interpretation of it, is attacked by the three character-narrators who have more or less violently broken away from the hold of the three institutions - the husband, society and religion - which they identify as male serving interests. Toward the end of the story, Nafi seems to be less and less interested in religion. She rejects her father's use of religious discourse to make her endure her difficult marital situation: "In his last letter my father talked of God. It's not a question of Him, but of me - me, very much alive" (75). She means that God has nothing to do with her plight, and that she will no longer cope with the coercive role of religion. In fact, she deliberately leaves her religious identity obscure: "I've two neighbors, the one in the bed left is an Arab, she thinks I'm a Muslim; the one on the right is Italian, and she thinks I'm a Roman Catholic" (73). Her refusal to baptize the baby according to the Muslim or the Christian rites is telling about her disillusionment by religion.

Ramatoulaye's verbal rage before the Imam, the religious personality, is an act of defiance as well. Raised according to the religious dogmas to believe in fate, she was very complacent at the beginning of the story, enduring the husband's and in-laws' whims. The use of the figure of the Imam to announce the second marriage of her husband is symbolical because he represents the religious and moral authority, a living reminder of the precepts among which is the acceptance that accompanies fate. That is why, when Tamsir decides to declare his love to Ramatoulaye to inherit her from his deceased brother, he finds it necessary to be accompanied and witnessed by the Imam to secure Ramatoulaye's consent. But the lady's satirical speech, mocking, satirizing, provoking against the suitor and before the Imam is considered by the latter as blasphemy: "The Imam prayed God to be his witness. 'Such profane words and still in mourning!" And she does it on purpose, as she reveals: "Thus I took my revenge for that other day when all three of them had airily informed me of the marriage of Modou fall and Binetou" (58).

By asserting herself in this manner, Ramatoulaye deliberately chooses to shock Tamsir as well as the Imam at his side. A reader aware that the simple presence alone of the Imam in a social setting demands for both restraint and respect, can accurately measure the impact of such transgressive behavior and the heroine's determination to challenge certain social norms. (Guèye, Médoune, 2003) 
However, in the religious field, Celie's rebellion is more violent because she overtly apostatized. A fervent believer at the beginning of the story, who writes missives to God and asks Him to show her the way, by the end Celie eventually discards God and chooses her sister Nettie as the addressee of her letters. For her, God embodies the racist, white, male trope: "Ain't no way to read the bible and not think God white. [...] When I found out I thought God was white, and a man, I lost interest" (195). As Madigan citing Hankinson writes, "Celie's movement away from a traditional monotheism to a sort of pantheism is paralleled by 'a new sense of bonding with other women' as well as self-esteem" (Madigan, 2006: 226). We see this in this blasphemous paragraph wherein Celie unfolds her grudges against her formerly worshipped God:

Yeah, I say, and he give me a lynched daddy, a crazy mama, a lowdown dog of a step pa and a sister I probably won't ever see again. Anyhow, I say, the God I been praying and writing to is a man. And act just like all the other mens I know. Trifling, forgetful and lowdown. [...] Let him hear me, I say. If he ever listened to poor colored women the world would be a different place, I can tell you. (192)

Pointing that men "are sadly unable to fulfill the social role given to them through the intervention of the patriarchal tradition, (the writers) disrupt those very structures which have always favored the silence of women in order to inscribe a new discourse" (Guèye, M, 2006: 53). The new discourse of the main character-narrators is one which reclaims women's agency, values her self-confidence, and promotes sisterhood.

\section{Reclaiming agency with a derisive discourse}

Toward the end of the novels, each of the three narrators finds the energy and resources necessary to come to peace with herself after an internal struggle to yoke the demons of the past. Rama, Nafi and Celie prove that they are no longer willing to serve as silent objects; rather, they affirm and embody their new-found personalities. They are the types of victims of trauma who "re-member their fragmented selves with I-narration" (Ngom 2014) to recover selfhood and attain wholeness.

Indeed, I-narration in homodiegetic narrative, when the narrator is at the same time the object of the narrative (Genette, 1980), may equate to mending and healing the self. It serves as introspection, allowing the narrator to plunge into the inner self to assess where the matter has stuck, where things have degenerated. So this healing is a kind of empowerment through 
knowledge - a personal development that conjures self-hatred or lack of selfesteem.

In fact, for the three of them the simple act of writing their long suffered experiences is an act of claiming agency. From silent, enduring subjects, they endeavor to regain agency. The narrative is thus tantamount to a kind of "empowerment through the pen" (Dieng 2011: 22). Van der Merwe and Gobodo-Madikizela rightly put that "reconstructing the trauma into narrative form is one of the most crucial processes in the journey towards the victim's healing"' (qtd Coulibaly, 2014: 44).

Therefore, the pen becomes a liberating tool that enables these female characters to create meaning and to redefine themselves and their surrounding worlds. Describing themselves and their environments in their own meanings equates to owning that which they describe. In fact, naming begins to pave the way towards the process of ownership (Ngũgĩ, 2009: 7). In addition, by parodying the patriarchal discourse and opposing it to their own, the three narrators of the stories engage in a process of creation of sense and meaning, an ensuing semantic battle which is an act of rebellion. We can assert like Scott that "Such works represent heroic acts of attack on the dominant semantic domain where they were defined as chattel property, pseudo-females or repositories for male's physical and psychic abuse" (Scott, 1993: 67).

The denouement of the stories, by the conditioning of round characters changing for the best, reveals feminism at work. Ramatoulaye, Nafi and Celie attain selfhood and wholeness again when they come full circle through the tremendous journey of their existence. The cathartic journey entails an identity quest and affirmation whose stake is to confront the devils of one's past through a view of conjuring them and examining them head on. It is generally described by psychologists as a painful experience that involves a voyage into the past, psychologically or physically, to the traumatic episodes and places of one's life (Coulibaly, 2014: 28). This confrontation does not do away with violence, but it is rather a voluntarily self-inflicted pain to relive traumatic experiences with the aim of casting them away.

The three stories valorize identity construction and self-affirmation. The narrations capture the characters' initial nervous conditions and their evolution from psychological breakdown into strong personality. All three characters show a kind of maturity, acquired through difficult circumstances. These difficulties that took them unawares have at least the merit of forging their new identities. So the denouement of the narratives stands for selfacceptance, celebrations of newly-won independence. Ramatoulaye, Nafi, and Celie no longer define themselves under male tutelage, neither the father's nor the husband's.

Ramatoulaye is ready to face the judging gaze of the chauvinistic society, as she now regularly goes out - a single unaccompanied lady - to the 
cinema. If before she couldn't picture her life without the protective shadow of a loving man, she's now ready to face the lashes of life alone. A lady with twelve children, she chooses to cope with her new role as a single parent rather than to remarry. If this task was imposed to her by her deserting husband, now she chooses in full knowledge of the difficulties to provide for herself and family, as she has been doing for five years. The sweet taste of this new-found independence drives her to dispel different kinds of suitors who have diverse and varied motivations and expectations. In addition, she will remain unmarried because of her disillusionment in man and her faithfulness in sisterhood, to the extent of not wanting to cause another woman's misfortune.

Likewise, Celie is no longer bound by her society's principles and canons. She becomes whole again when she derides the archetypal trio of male figures: the father, husband, and God. Now she is master of herself and of her body. This newly constructed identity is expressed through the image of sisterhood with Shug Avrey, who liberates Celie sexually and economically. Celie's new personality, revealed through her pants and nonconformist attire, foregrounds a self-assertive woman that breaks away from the society's canons. Indeed, derision is a privileged weapon against the common sense esthetic criteria (Heinich, 2001: 123). Therefore she stands up to her husband's and beyond, the society's denigrations, proudly re-appropriating the defaults they associate with her: "I'm pore, I'm black, I may be ugly and can't cook, a voice say to everything listening. But I'm here" (207). Herewith Celie's discourse can be interpreted with Feuerhahn's assertion that self-derision is a counter-stigmatization which defuses derision of its negative load, contributes to the identity expression, and fights against assimilation (Feuerhahn, 2001: 195). In fact, Celie's defying affirmation of selfhood by "I'm here" boldly sounds the knell of self-hatred and self-abashing.

Nafi, who passively and silently accepted her miserable life in France as a demonstration of her own mistakes and of her respect for her father's decision, eventually takes the resolution to discard everything and quit. She decides, despite what society may think, to leave her husband because she can no longer stand their life together. The howling baby and the consistently damp and soiled nappies aggravate her condition. "It'll be the death of me! No, I can't stay here - they can think what they like. Stay and wait for him to get better? He never will get better. He wanted a young wife to end his days with. I don't want to die - not here (75). This affirmation of her wish to live counters her previous desires to die that resulted from hate of herself.

Moreover, very respectful of her father at the beginning of the story, Nafi starts seeing her affection melting away from the one she once considered very gentle and soft. Although in the beginning she strived to dispel the idea of her father's participation in the machinery that caused her downfall, more and more she can no longer resist the evidence. In her gloomy situation, Nafi 
receives occasional letters from her father intended to encourage her endure. The letters laud the quality of a "submissive wife, a sort of unobtrusive shadow" (73). However, she now mocks the posture of this piece of advice, showing the ease and hypocrisy of the advisor: "In his last letter my father talked of God. It's not a question of Him, but of me - me, very much alive. I've stopped replying to father's letters. It's better that way. One of these fine mornings he'll see me arrive. When I left I was just a child - in my mind - but I'm not any longer' (75).

The maturity brought about, not simply by age, but rather by hard lived experiences, is shared by the three main characters. Their sudden maturity, expressed through the ability to parody and find irony raises them to be a notch superior to their oppressors. Thus derision, in the three novels, operates also through condescension. This is a subversive expression of the norms accepted by society that say that men are more responsible and superior to women. Indeed, in a condescending manner, the three characters expose the failings of men, transcend these, and forgive them. The capacity to forgive is proof of magnanimity and the grandeur which the men in these stories are found wanting.

Forgiveness is an important step to self-reconciliation in the process of mending and healing the psychological wounds. In fact, these victims can only turn the dark pages of their gloomy pasts and resolutely move ahead when, after confronting this haunting past, they decide to forgive - themselves first and then their oppressors. Indeed, according to Rubin "Compassion is the strongest human therapeutic agent in existence. Its potential for constructive growth and human creative possibility is almost limitless" (Rubin, 1998: 16). Forgiving is proof that you have come through and moved past the difficulties. Paraphrasing Matt Atkinson, one can surmise that these characters have evolved from victims to survivors of trauma, meaning they have coped with, and successfully transcended, their trauma (Atkinson, 2008).

Cleansing the mind from hatred - of oneself and of the others - and untying the heart's revengeful knots is the premise of starting life anew. Despite their plight, all three characters are able to draw upon their deep inner strengths the courage to forgive their oppressors. Celie fights the criminal bouts towards her husband. With the help of Shug, she expiates the desire to kill her husband, for she understands that killing would never liberate her totally. To be liberated altogether, physically and psychologically, one must overcome the obstructing past - not by killing or ignoring it, but by transcending it after addressing it head on. Indeed, Celie even pays visit to her now ex-husband to whom she offers friendship. Ramatoulaye forgives and prays every day for her dead husband despite his years of betrayal. Moreover, she even pities her co-wife, Binetou, whom she describes as a child stripped of her childhood and innocence to be sold by deprived parents to a lusty and 
irresponsible man who could be her father. In the same vein, Nafi is ready to make a future for herself instead of bearing a grudge against her father or her husband. She eventually finds compassion for her husband, and says she understands his situation and that of his immigrated friends. The derisive mood of the narration finds, if not justification, at least an explanation for the rationale which sustains men's attitudes. The latter are associated with factors that go beyond the individual characters' experiences to find deep roots pervasive throughout society. Searching their inner motivations and psychoanalyzing their detractors allows the epistlers to extend compassionate explanations to them.

\section{Conclusion}

A study of (self)derision in So Long a Letter by Mariama Ba, Letters from France by Sembène Ousmane and Alice Walker's The Color Purple informs the main characters' moral and psychological growth. According to Atkinson (2008), this kind of evolution reveals the transformation from victims to survivors of trauma. We notice that derision is at first used as a selfdestructive weapon by tormented characters, victims of different crises like abandonment, sexism, and racism and who, because of psychological posttraumatic sequels, despise themselves more than they do their assaulters. Selfinflicted pain is meant to be a purgatory of torture for characters, who genuinely believe they deserve what befell them. Another use of derision in these stories is tantamount to a particular stage of the characters' development wherein, with the intervention of some external factors, they redirect the derisive language to aim at institutions like religion, "rigid traditions", "endemic sexism", and "patriarchal attitudes" that are now viewed as "a hegemonic system that nourishes and protects (men's) interest" (Azodo, 1997: 201). Another phase of growth corresponding to recovered selfhood and wholeness is attained through compassion and forgiveness.

Whether reflexive or extensive, derision is used as an esthetic trope, a cathartic tool to expose the wantings and failings of the self and its society. The infusion of satirical, dark humor as a backdrop in these narratives through characters poking fun at themselves and their societies serves many purposes: cathartic healing process that prevents madness, it is a resistance weapon against the "sacred" through subversion and transgression, and it is also a vital tool for construction of self-identity and affirmation of self-agency.

\section{References:}

1. Abbandonato, Linda (1991) ""A View from 'Elsewhere' ": Subversive Sexuality and the Rewriting of the Heroine's Story in The Color Purple", PMLA, vol. 106, n 5 
2. Atkinson, Matt (2008) Resurrection after Rape: A Guide for Transforming from Victim to Survivor, Oklahoma City: R.A.R. Publishing

3. Azodo, Ada Uzoamaka (1997) "Issues in African Feminism: A Syllabus Source: Women's Studies", Quarterly, Vol. 25, No. 3/4, Teaching African Literatures in a Global Literary Economy

4. Ba, Mariama (1981) So Long a Letter. Trans. M. Bode-Thomas, London: Heinemann

5. Baldick, Chris (1990) The Concise Oxford Dictionary of Literary Terms, Oxford: Oxford University Press

6. Bestman, Martin T(1981) Sembène Ousmane et l'esthétique du roman négro-africain,

Québec: Editions Naaman

7. Bonnafous, Simone (2001) «L'Arme de la dérision chez J.-M. Le Pen », HERMĖS 29

8. Bruner, Charlotte H. (1990) "Women Viewed and Women Viewers in African Literature", Africa Today, Vol. 37, $\mathrm{N}^{\circ}$ 1, After the Women's Decade: The Task Ahead for Africa

9. Case, F. (1981) "Workers Movements: Revolution and Women's Consciousness in God's African Studies, Vol. 15, No. 2

10. Cham, Mbye B. (1985) "Islam in Senegalese Literature and Film", Africa: Journal of the International African Institute, Vol. 55, $\mathrm{N}^{\circ} .4$, Popular Islam

11. Chimoun, Mosé (1998), « L'Image de l'homme dans la littérature féministe ", Langues et Littératures, Revue du GELL, N², pp. 17-29.

12. Coulibaly, Bojana (2017) L'Invention du quotidien dans la nouvelle oust-africaine d'expression anglaise, Paris: Harmattan

13. Coulibaly, Bojana (2014) "Haunting of the Return in Boubacar Boris Diop's Thiaroye: terre Rouge and Murambi: le livre des ossements", Boubacar Boris Diop: une écriture déroutante. Boubacar Camara \& Ousmane Ngom ed. Langues et Littératures, Revue du Gell

14. Dehon, Claire L. (1996), "Women in Black African Novels Written in French", NWSA Journal, Vol. 8, N. 1, Global Perspectives

15. Dieng, Babacar (2011) "Men Trading Wives for Younger Women: Freudian Overtones in the Representation of Midlife Crisis in Jazz and So Long a Letter", SAFARA No. 9 \& 10

16. Doquet, Claire et Leblay Christophe (2014) «Temporalité de l'écriture et génétique textuelle: Vers un autre métalangage ? », SHS Web of Conferences 8

17. Fontanier, Pierre (1977) Les Figures du discours, Paris: Flammarion

18. Feuerhahn, Nelly (2001) «La dérision, une violence politiquement correcte », HERMÉS 29 
19. Fry, Northrop (1973) Anatomy of Criticism, Princeton: Princeton University Press

20. Genette, Gerard (1980) Narrative Discourse: An Essay in Method. Trans. Jane E. Lewin. New York: Cornell University Press

21. Gold, Hazel (1993) The Reframing of Realism. Galdos and the Discourses of the Nineteenth-Century Spanish Novel. London: Duke University Press

22. Griffin, Dustin (1994) Satire: A Critical Reintroduction, Lexington: University Press of Kentucky

23. Gueye, Marame (2012) "Stuck on So Long A Letter: Senegalese Women's Writings and the Specter of Mariama Bà", [online]

24. https://projects.ncsu.edu/aern/...1/AERN2012Summit_Gueye.pdf a paper presented at the 20th Anniversary Summit of the African Educational Research Network at North Carolina State University Raleigh, USA

25. Gueye, Médoune (2003) "Reading the postcolonial Paradigm in Mariama Ba and Simone Schartz-Bart: Resistance and Negotiation”, Bridges 9

26. Hamilton, Cynthia (1988) "Alice Walker's Politics or the Politics of The Color Purple", Journal of Black Studies, Vol. 18, N³

27. Heinich, Nathalie (2001) "Art contemporain, dérision et sociologie", HERMÈS 29

28. Hellenbrand, Harold (1986) "Speech, after Silence: Alice Walker's The Third Life of Grange Copeland", Black American Literature Forum, Vol. 20, $\mathrm{N}^{\circ}$. 1/2

29. Hogue, W. Lawrence (1985) "History, the Feminist Discourse, and Alice Walker's The Third Life of Grange Copeland", MELUS, Vol. 12, $\mathrm{N}^{\circ}$. 2, Black American Literature

30. Kamara, Gibreel M. (2001) "The Feminist Struggle in the Senegalese Novel: Mariama Ba and Sembene Ousmane" Journal of Black Studies, Vol. 32, $\mathrm{N}^{\circ} .2$

31. Lewandowski, Marcin (2010) "Sociolects and Registers - a Contrastive Analysis of Two Kinds of Linguistic Variation", Investigationes Linguisticae Vol. XX

32. Linkhorn, Renée (1986) «L'Afrique de Demain: Femmes en marche dans l'œuvre de Sembène Ousmane », Modern Language Studies, Vol. $16, \mathrm{~N}^{\circ} .3$

33. Madigan, Kathleen (2006) "Models of Solidarity in Alice Walker's The Color Purple", Tradition and the Dynamics of Women's Empowerment, Dakar: Dakar University Press 
34. Madubuike, Ihechukwu (1975)) "The Politics of Assimilation and the Evolution of the Novel in Senegal", African Studies Review, Vol. 18, $\mathrm{N}^{\circ} .2$

35. Mcdowell, Deborah E. (1987) ""The Changing Same": Generational Connections and Black Women Novelists", New Literary History, Vol. 18, No. 2, Literacy, Popular Culture, and the Writing of History

36. Ngom, Ousmane (2014) "Boubacar Boris Diop: The Achievement of the Craft of I-Narration", Boubacar Boris Diop. Une écriture déroutante. Coordonné par Boubacar Camara et Ousmane Ngom. Langue et Littérature Revue du GELL, H.S. N 1

37. Ngom, Ousmane (2012) Stratégies narratives dans la littérature africaine et afro-américaine: étude comparative des romans de Ngũgi wa Thiongo, Sembène Ousmane et Alice Walker, Saabrücken : Presses universitaires européennes

38. Ngũgĩ wa Thiong'o (2009) Something Torn and New: An African Renaissance, New York: Basic Book

39. Rainville, Pierre (2015) « Paroles de déraison et paroles de dérision : les excès de langage à l'épreuve du droit criminel canadien », RJTUM 35

40. Rey-debove, Josette (1982). "Pour une lecture de la rature", La Genèse du texte: les modèles linguistiques, ed. CNRS

41. Rose, Margaret A. (1993) Parody: Ancient, Modern, and PostModern, Cambridge: Cambridge University Press, 1993

42. Rubin, Theodore I (1998) Compassion and Self-hate: an Alternative to Despair, New York: Touchstone

43. Sembene, Ousmane (1962) "Letters from France" Tribal Scars and Other Stories [online]Digitalized by. RevSocialist for. Socialist Stories.

44. http://www.socialiststories.com/liberate/Tribal\%20Scars $\% 20$ and $\% 20$ Other\%20Stories\%20-\%20Sembene\%200usmane.pdf

45. Scott, Joyce Hope (1993) "Bodies of Text and Texts of Bodies: (Re) Presentation of Slavery in African-American Women's Fiction”, Bridge N'5-6

46. Tucker, Lindsey (1988) "Alice Walker's The Color Purple: Emergent Woman, Emergent Text”, Black American Literature Forum, Vol. 22, $\mathrm{N}^{\circ}$ 1, Black Women Writers Issue

47. Walker, Alice (1983) In Search of Our Mothers' Gardens, London: The Women's Press

48. Walker, Alice (1982) The Color Purple, New York: Harvest, [Harcourt Brace Jovanovich, 1970] 
49. Worthington, Pepper (1985) "Writing a Rationale for a Controversial Common Reading Book: Alice Walker's The Color Purple", The English Journal, Vol. 74, $\mathrm{N}^{\circ} .1$ 